\title{
Hemorrhagia neonatorum vel maternorum?
}

Blod

Føtalt blod
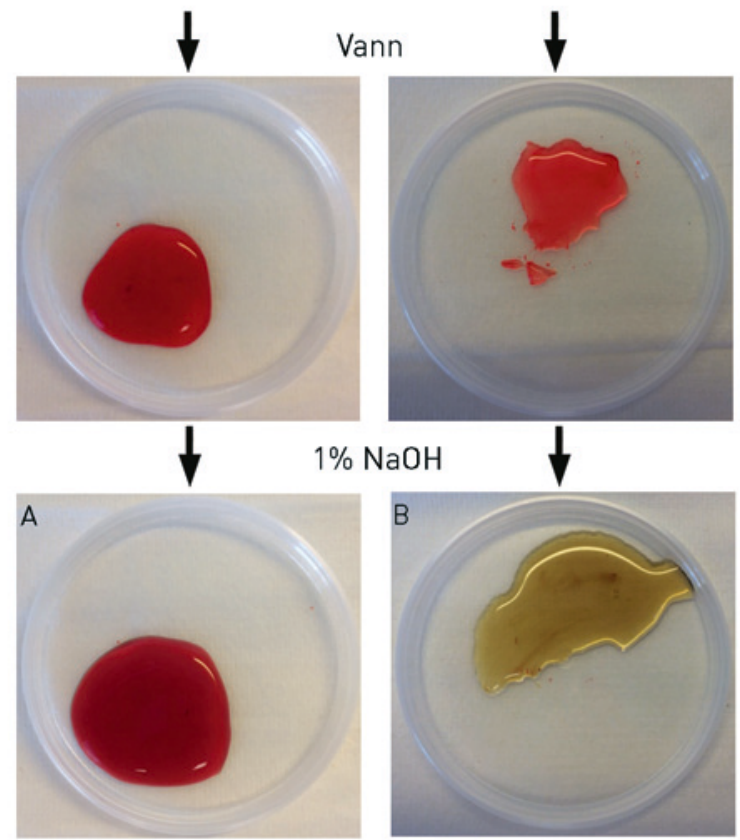

Maternelt blod

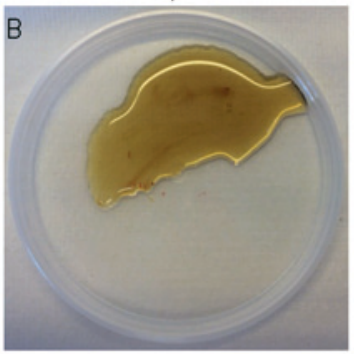

Blodtilblandet feces

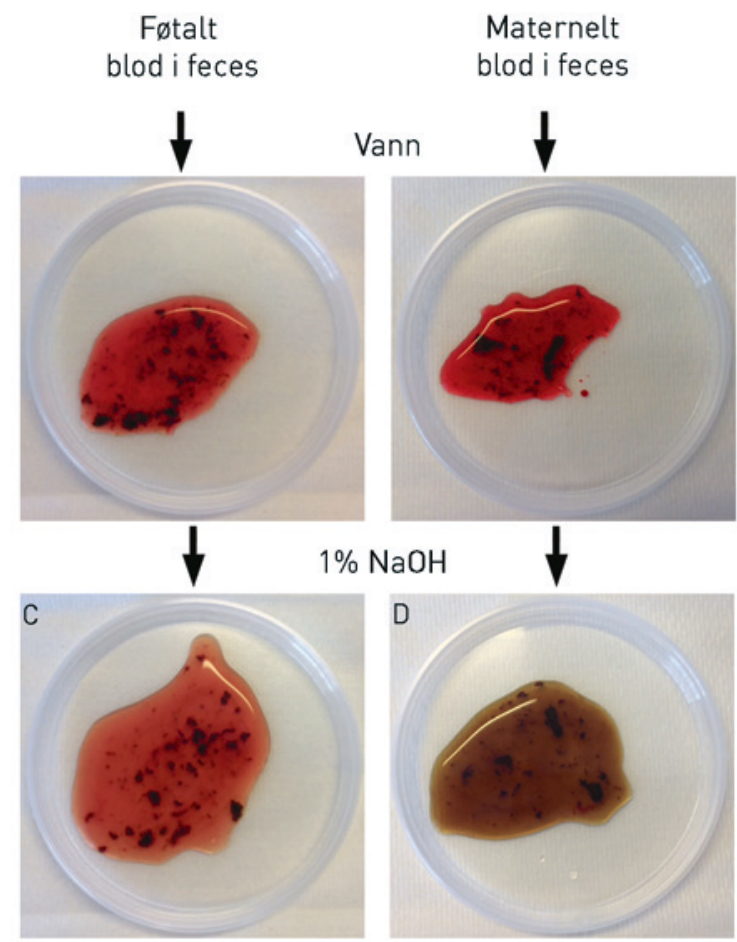

Blodig avføring hos nyfødte kan være et uttrykk for alvorlig underliggende sykdom, men kan også skyldes svelging av mors blod i forbindelse med forløsning eller amming. Påvisning av mors blod i avføring vil kunne begrense utredning med unødvendige blodprøver, radiologiske undersøkelser og kirurgiske prosedyrer.

Som ledd i utredning av nyfødte med blodig avføring utviklet Leonard Apt i 1955 en kvalitativ prøve for å skille føtalt hemoglobin $(\mathrm{HbF})$ fra maternelt (HbA) (1). Metoden baserer seg på at maternelt hemoglobin denatureres til hematin (gulbrun/grønn farge) når eksponert for basisk løsning (natriumhydroksid), mens føtalt hemoglobin er mer stabilt mot slik denaturering. Apt validerte metoden på nyfødte med nasogastrisk sonde tilført navlestrengs- og maternelt blod, og senere studier har bekreftet Apts prøve som en pålitelig, enkel, rask og pasientnær undersøkelse for å differensiere mellom føtalt og maternelt blod $(2,3)$.

Prøven er etter vår erfaring lite kjent, men kan være nyttig å kjenne til for alle som møter nyfødte i klinisk praksis. Den utføres ved at tilstrekkelig mengde prøvemateriale (friskt blod, blodtilblandet feces eller oppkast) føres over $\mathrm{i}$ en beholder eller et reagensrør. Noen milliliter rent vann tilsettes. Dette hemo- lyserer røde blodceller, og fritt hemoglobin blir tilgjengelig. Noen milliliter $1 \%$ natriumhydroksid $(\mathrm{NaOH})$ tilsettes, og det blandes forsiktig.

Prøven observeres så for fargeomslag. En løsning som ikke endrer farge, indikerer hemoglobin som er stabilt mot denaturering, og gir mistanke om føtalt blod (A, C). En løsning som raskt endrer farge til en gulbrun eller grønn farge indikerer hemoglobin som denatureres, og gir mistanke om maternelt blod (B, D). En kontrollprøve uten tilsatt lut kan benyttes for sammenligning, og fargeomslag bør forekomme innen to minutter. For korrekt tolkning bør prøven utføres innen 30 minutter (3).

\section{Tormund Salvesen Njølstad}

tormund.njolstad@gmail.com Wiebke Sivertsen

Friedrich Reinhart-van Gülpen

Beate Horsberg Eriksen

Barne- og ungdomsavdelinga

Ålesund sjukehus

Tormund Salvesen Njølstad (f. 1988) er turnuslege.

Forfatter har fylt ut ICMJE-skjemaet og oppgir ingen interessekonflikter.
Wiebke Sivertsen (f. 1985) er lege i spesialisering.

Forfatter har fylt ut ICMJE-skjemaet og oppgir ingen interessekonflikter.

Friedrich Reinhart-van Gülpen (f. 1969) er overlege og spesialist i pediatri.

Forfatter har fylt ut ICMJE-skjemaet og oppgir ingen interessekonflikter.

Beate Horsberg Eriksen (f. 1969) er overlege og spesialist i pediatri og har en ph.d.-grad innen barnekardiologi.

Forfatter har fylt ut ICMJE-skjemaet og oppgir ingen interessekonflikter.

Litteratur

1. Apt L, Downey WS Jr. Melena neonatorum: the swallowed blood syndrome; a simple test for the differentiation of adult and fetal hemoglobin in bloody stools. J Pediatr 1955; 47: 6-12.

2. Apt L. Melena neonatorum; an experimental study of the effect of the oral administration of blood on the stools. J Pediatr 1955; 47: 1-5.

3. McRury JM, Barry RC. A modified Apt test: a new look at an old test. Pediatr Emerg Care 1994; 10 : 189-91. 